УДк $502.35: 504.03$

\title{
ПРИНЦИПИ ОЦІНКИ ЕКОЛОГІЧНИХ СИТУАЦІЙ
}

\author{
Г.Д. Гуцуляк \\ доктор економічних наук, професор \\ член-кореспондент НАAH \\ Прикарпатська державна сільськогосподарська дослідна станція Інституту сільського \\ господарства Карпатського регіону \\ (Україна, м. Івано-Франківськ, e-mail:dubkosiv@gmail.com) \\ Ю.Г. Гуцуляк \\ доктор економічних наук, старший науковий співробітник \\ Прикарпатська державна сільськогосподарська дослідна станція Інституту сільського \\ господарства Карпатського регіону \\ (Україна, м. Івано-Франківськ, e-mail: yuriy.kosiv@gmail.com)
}

\begin{abstract}
Визначено чинники, які необхідно всебічно враховувати при веденні інтенсивної господарсъкої діяльності, що своєю чергою, потребує глибокого вивчення екологічних особливостей навколишнъого природного середовища, складних $і$ взаємозалежних явищ, які відбуваються в біосфбері під впливом господарсъкої діялъності людини, різноманітних суспільно-політичних, соціалъно-економічних, виробничих $i$ демограбфічних процесів. Обгрунтовано приницпи, якими необхідно керуватися під час виконання конкретних завданъ просторового аналізу екологічних ситуаиій та їх оиінки: приниип залежності бормування $і$ розвитку екологічних ситуачій від природних $і$ соиіально-економічних чинників; приниип відповідності (невідповідності) антропогенного навантаження потенціалу стійкості і природно-ресурсному потенціалу ландшафбт; принцип екологічної значущості природних $і$ сочіально-економічних чинників; принцип пріоритетності; принцип тривалості, переривчастості розвитку екологічних ситуачій; принщип небезпеки і ризику виникнення екологічної ситуачїі; модульний принцип; комбіначійний приниип.
\end{abstract}

Ключові слова: принципи, господарсъка діяльність, екологічні особливості, навколишнє природне середовище, господарсъка діяльність, антропогенний вплив.

Постановка проблеми. Дедалі більшого значення набуває просторовий аналіз, тобто сукупність аналітичних методів для вивчення просторової диференціації екологічних проблем та розв'язання відповідних ситуацій. Як прийом наукового мислення просторовий аналіз може бути розглянутий в аспекті наукового підходу в тісному взаємозв'язку з регіональною геоекологією, насамперед щодо регіонального та антропоцентричного характеру розгляду проблем.

Негативні зміни довкілля внаслідок взаємодії природи і людини, що зумовлює порушення структури й функціонування екосистем (ландшафртів), призводить до екологічних, соціальних, економічних та інших наслідків, належать до екологічних проблем. Таке розуміння не суперечить подвійному визначенню проблеми: по-перше, її виникнення потребує відповідних заходів для відновлення (охорони) природних середовище- та ресурсоформуючих процесів, а також ресурсозберігаючих властивостей ландшафтів, а по-друге, в екологічному аспекті - ті самі процеси і властивості ландшафтів, що фрормують навколишнє природне середовище, мають важливе значення, насамперед, для людини.

Екологічна ситуація є комплексним питання, що налічує, зокрема, негативні і позитивні чинники та умови з погляду проживання і стану здоров'я людини на території різного ступеня благополуччя і неблагополуччя. Під екологічною ситуацією розуміємо певний стан навколишнього природного середовища, обумовлений взаємодією природи і господарської діяльності людини, особливо під час землекористування [1].

Екологічна ситуація (наразі розглядаємо несприятливу) є просторово-тимчасовим поєднанням екологічних проблем, що визначають стан систем життєзабезпечення людини $\mathrm{i}$ утворюють певні екологічні умови на території різного ступеня неблагополуччя (гостроти).

Головна увага в цьому питанні приділяється навколишньому природному і природно-антропогенному (природно-техногенному) середовищам - ареалу життєдіяльності людини. Таке обмеження передбачає розгляд тільки конкретного середовища, хоча все навколишнє середовище є взаємопов'язаним, ди- 
ференційованим і інтегрованим у різні утворення.

Аналіз останніх досліджень і публікацій. На сьогодні фундаментальні дослідження проблем оцінки екологічних ситуацій широко висвітлено в економічній науці. Серед визнаних учених, які зробили вагомий внесок у вивчення цих проблем, слід відзначити Е. Альфреда, К. Гофрмана, Ф. Кене, Р. Коуза, Д. Медоуза, Ю. Одума, А. Пігу, М. Реймерса, К. Ріхтера, Дж. Форестера та ін. Їх теоретичні надбання набули подальшого розвитку у наукових працях вітчизняних вчених, зокрема О.Ф. Балацького, I.К. Бистрякова, Б.В. Буркинського, С.П. Іванюти, Л.В. Жћарової, А.Б. Качинського, I.M. Лицура, В.О. Онищенка, В.Г. Потапенка, О.В. Прокопенко, О.Ф. Савченка, М.С. Самойлік, П.М. Скрипчука, А.В. Степаненка, С.К. Харічкова, Є.В. Хлобистова та ін.

Виділення невирішених раніше частин загальної проблеми. Комплексне вивчення довкілля неможливо без розгляду сорормованих чи тих, що формуються, природно-антропогенних геосистем (у межах ареалів екологічних ситуацій). Територіально пов'язані екологічні проблеми чи їх комплекс, що характеризуються певною спільністю: єдністю території, чинником виникнення, певним набором проблем i ступенем їхньої гостроти - визначають стан екосистеми. Вводячи це поняття, підкреслюємо тим самим його антропоцентричну сутність і системне уявлення про навколишнє природне середовище.

Джерелами появи проблем і розвитку екологічної ситуації є розходження в структурі і функціонуванні природних систем та соціально-економічних утворень, а також невідповідність характеру і рівню антропогенних впливів потенціалу природи (стійкості, самоочищення тощо). Отже, розв'язання екологічних проблем зводиться до аналізу співвідношення антропогенного навантаження і властивостей ландшафрт, внаслідок чого можуть бути виявлені негативні щодо умов життєдіяльності людини зміни в ландшафртах і навколишньому природному середовищі (забруднення повітря, виснаження запасів прісних вод, ерозія грунтів тощо)

Метою дослідження є обгрунтування концептуальних засад та принципів оцінки екологічних ситуацій в контексті сталого розвитку суспільства.

Викладення основного матеріалу дослідження. Через значне різноманіття завдання просторового аналізу екологічних ситуацій та іх оцінки складно розраховувати на вироблення єдиного, придатного для всіх ситуацій інструментарію. Просторовий аналіз, призначений для дослідження такого складного явища, як екологічна ситуація, обумовлено сукупністю методів.

Спосіб і результати просторового аналізу визначаються цілями дослідження і характером об'єкта аналізу. Метою просторового аналізу екологічних ситуацій та їх оцінка є вивчення просторової і тимчасової диференціації екологічних ситуацій, чинників її фрормування, а також особливостей і закономірностей утворення сполучень елементів і компонентів цієї ситуації. Характер об'єкта аналізу визначається через його опис, де наводяться основоположні і значущі характеристики. Важливим завданням є вирішення питань використання інформації, насамперед вибір і уніфікація шкал вимірювання показників [2]. Відповідно до мети і об'єкта дослідження вибираються методи вивчення цих ситуацій.

Загальна логічна послідовність найважливіших операцій просторового аналізу екологічних ситуацій зводиться до низки етапів, яК-ОТ:

1) формування цілей і завдань, робочих гіпотез і принципів, визначення методів і організація дослідження;

2) інвентаризація і класифікація екологічних проблем та ситуацій;

3) оцінка екологічних проблем і ситуацій за наперед визначеними критеріями згідно із заданими нормами і цілями;

4) виявлення екологічних проблем і їхня локалізація, визначення ареалів екологічних ситуацій, встановлення меж, вибір масштабів картографування, складання карт, районування території;

5) характеристика просторової диференціації екологічних ситуацій;

6) прогнозування і ризик виникнення екологічних ситуацій;

7) підходи до розв'язання екологічних проблем і запобігання їх виникненню.

Для виконання конкретних завдань просторового аналізу екологічних ситуацій та їх оцінки використовуються спеціальні методи. Значно ширшу сореру застосування мають фрундаментальні ідеї і принципи (системний, географічний, історичний, антропоцентричний підходи, концепція ноосфери), що носять загальнометодологічний характер і є основою для розробки спеціальних методів.

Серед принципів, якими керуються під час виконання конкретних завдань просторового аналізу екологічних ситуацій та їх оцінки, слід виокремити:

1) принцип залежності фрормування і розвитку екологічних ситуацій від природних і соціально-економічних чинників; 
2) принцип відповідності (невідповідності) антропогенного навантаження потенціалу стійкості і природно-ресурсному потенціалу ландшафту;

3) принцип екологічної значущості природних і соціально-економічних чинників;

4) принцип пріоритетності;

5) принцип тривалості, переривчастості розвитку екологічних ситуацій;

6) принцип небезпеки і ризику виникнення екологічної ситуації;

7) модульний принцип;

8) комбінаційний принцип.

Відповідно до специфріки об'єкта і мети дослідження під час просторового аналізу екологічних ситуацій використовуються певні підходи і методи: порівняльний, ландшафтний і геосистемний підходи, метод оцінки, класифікація, районування, методи вивчення використання земель, складання карт, картометрический метод, використання космознімків, аналіз матеріалів соціально-економічної статистики і даних моніторингу, експертні оцінки, методи прогнозування.

За останні два століття населення земної кулі, чисельність якого за цей час зросла майже в 5 разів, надто змінило навколишнє природне середовище. Внаслідок збільшення потреб у продуктах харчування, нарощування обсягів використання природних багатств та обміну між суспільством і природою значні земельні площі, що колись були під незайманими лісами, нині залучено до господарського обігу — розорано та перетворено на сільськогосподарські угіддя. Зокрема, створено масштабні штучні водойми, змінено течії багатьох рік, осушено вікові болота тощо. Людство дедалі більше освоює та інтенсивно використовує ресурси земної біосорери, зокрема й Світового океану.

Гігантські масштаби індустріального розвитку та видобутку різних видів мінеральної сировини й енергетичних ресурсів призвели до надзвичайно швидких темпів зростання антропотехногенних навантажень на природу, посилення забруднення довкілля шкідливими промисловими викидами і відходами, прискорення темпів деградації навколишнього природного середовища та збіднення і вичерпання деяких його ресурсів. Інтенсифікація аграрного виробництва на основі застосування дедалі більших обсягів мінеральних добрив, пестицидів, гербіцидів та інших агрохімікатів зумовлює майже повсюдне забруднення грунтів, поверхневих і підземних вод, а відтак - продукції рослинництва й тваринництва, продовольства. Все це, безперечно, значною мірою вплинуло на природні умови життя людей, значно змінило не лише природні, зокрема кліматичні, процеси, а й якість навколишнього природного середовища з погляду інтересів здоров'я населення.

Слід зауважити, що людство, яке інтенсивно використовує для власних потреб і, відповідно, інтенсивно змінює природу, ніколи не зможе звільнитися з-під влади її законів, з-під іï впливу. Хоча останній, як свідчить практика, в різні епохи цивілізації проявляється неоднаково. Людина була, є і залишиться невід'ємною складовою частиною біосфери. За всю історію існування людський організм за своєю будовою та фрункціями пристосувався до певних природних умов земної кулі, поза межами яких людина не зможе жити.

Зв'язок між природними умовами, якістю деяких природних ресурсів і навколишнього природного середовища загалом, з одного боку, та здоров' ям населення, з іншого, - очевидний і цілком закономірний. Від екологічного стану та чистоти атмосферного повітря, водойм, земельних ресурсів, рослинного й тваринного світу залежать фізичний та психічний розвиток, працездатність і довголіття народонаселення. Щоб людина була здоровою і витривалою, вона повинна споживати екологічно чисті продукти харчування і питну воду, дихати чистим повітрям тощо.

Екобезпечні навколишнє природне середовище, морське і лісове повітря, де кількість кисню в середньому на $15 \%$ є більшою, ніж у закритих міських приміщеннях, купання в морі та інших водоймах, звичайно екологічно чистих, перебування в специфічних гірських умовах тощо - все це сприятливо позначається на здоров'ї населення. Тобто людина повинна якнайтісніше спілкуватися з природою. Дуже слушно зауважив відомий французький учений минулого століття, один із фрундаторів сучасної фрізіологічної науки Клод Бернар: «Зрештою, життя — це лише відносини між організмом та навколишнім середовищем» [3].

Проблема оцінки впливу різних чинників навколишнього природного середовища як антропотехногенного, так і природного походження, екологічної ситуації, що складається в тому чи іншому регіоні й населеному пункті, на трудові ресурси, здоров' я людини та демографічні показники суспільства є на сьогодні однією з найактуальніших. Разом із тим мусимо констатувати, що багато питань такого впливу залишаються недостатньо дослідженими. Насамперед, це стосується з'ясування віддалених негативних наслідків впливу забруднення довкілля різними шкідливими інгредієнтами, ї канцерогенності, мутагенності й тератогенності на здоров' я і тривалість життя людини тощо.

Щодо змісту поняття «забруднення навколишнього природного середовища (природи, 
довкілля тощо)», то воно поки що не має чіткого визначення. На думку одних, антропотехногенне забруднення — це потрапляння в навколишнє середовище чи будь-яку його сореру або виникнення в них нових, звичайно нехарактерних елементів, а також перевищення в конкретний період природного середньобагаторічного рівня концентрації вказаних елементів та речовин у середовищі. Інші науковці вважають, що під забрудненням навколишнього природного середовища слід розуміти небажані зміни фізичних, хімічних та біологічних властивостей повітря, земельних і водних ресурсів, які негативно впливають на природу, виробничі процеси, умови життя людини та виснажують або роблять непридатними для користування сировинні ресурси. Також існує думка, що забруднення навколишнього природного середовища - це надходження в довкілля будь-яких твердих, рідких, газоподібних речовин або видів енергії у кількості, що перевищує граничнодопустимий рівень (який не спричиняє шкідливого впливу на людину, тваринний і рослинний світ) [4-10].

Цілком слушно, що якими б повними не були визначення цього поняття, вони не зможуть 3 необхідною повнотою розкрити суть вказаного явища, а саме - антропотехногенного забруднення земної біосфери. На нашу думку, найбільш відповідним і обгрунтованим є таке визначення, яке враховує кількість та концентрацію побічних шкідливих речовин та хімічних елементів, що потрапляють у довкілля внаслідок виробничої або іншої діяльності людини щодо їх негативного впливу, насамперед, на здоров' я населення, а також на процеси відтворення, обміну та споживання продукції.

Існування об'єктивних залежностей у системі «навколишнє природне середовище здоров'я людини», актуальність боротьби 3 різним захворюваннями населення, зумовленими екологічними чинниками, потребують розгортання широкомасштабних прикладних наукових розробок у цьому важливому напрямі. Адже будь-які захворювання завдають суспільству величезної соціально-економічної шкоди, а на лікування людини необхідні чималі додаткові витрати з державного чи сімейного бюджету. Слід додати, що до наукових пошуків з окресленої проблеми мають долучитися не лише медики, а й економісти, екологи, соціологи та представники інших галузей знань.

Останніми роками головна увага вченихекономістів була зосереджена на економічній оцінці шкоди, завданої трудовим ресурсам, населенню загалом забрудненням довкілля. Така шкода оцінюється, як правило, через величину суспільних затрат, зумовлених тимчасовою втратою працездатності внаслідок захворювання дорослих та дітей. Результати подібних розрахунків, дійсно, є доволі важливими; вони можуть бути використані для обгрунтування доцільності природоохоронних заходів, визначення еорективності інвестицій для їх реалізації тощо.

Однак шкода, завдана трудовим ресурсам і населенню, загалом, забрудненням навколишнього природного середовища не вичерпується, на нашу думку, тільки переліченими затратами суспільства, оскільки поняття «здоров'я населення» не є тотожним поняттю «відсутність захворювань». Адже у першому важливу роль відіграють і середня тривалість життя, і рівень смертності та народжуваності, й інші демографічні показники. Серед останніх особливе значення має приріст населення в аспекті трудових ресурсів, трудового потенціалу країни.

Тому поняття «здоров'я населення» $\mathrm{\epsilon}$ набагато ширшим, комплексним соціальногігієнічним та економічним показником, що інтегрує в собі демографічні, соціальні, екологічні й біологічні процеси, властиві людському суспільству, а також репрезентує рівень його соціально-економічного та культурного розвитку і стан природи в державі загалом. Іншими словами, здоров' я населення - це опосередкований інтегральний показник якості навколишнього природного середовища в найширшому його розумінні.

У соціально-економічному аспекті значної шкоди суспільству завдає низька середня тривалість життя людини, на яку негативно впливає висока дитяча смертність та інвалідність, розумова і фізична відсталість дітей. Саме ці показники значною мірою залежать від характеру та рівня забрудненості довкілля, насамперед повітря, водних ресурсів, а також продуктів харчування. За свідченням відомого вченого-гігієніста профресора Ф.Ф. Ерісмана: «Швидка зміна поколінь, яка є наслідком великої народжуваності і такої ж великої смертності, ні в якому разі не може вважатися доброю ознакою ні в санітарному, ні в економічному аспектах. Рання смертність дітей завдає країні непоправної шкоди, оскільки через вимирання дітей і через швидку зміну поколінь безповоротно втрачається весь запас праці, турбот та матеріальних засобів, які суспільство вклало в своїх рано загиблих членів» [11].

Так, антропотехногенні забруднення навколишнього природного середовища спричиняють численні захворювання, зокрема органів дихання, травлення, серцево-судинної системи, шкірного покриву тощо. Наприклад, за даними досліджень, проведених ученими Київського науково-дослідного інституту за- 
гальної і комунальної гігієни ім. О.М. Марзеєва, рак органів дихання на $45 \%$ зумовлено забрудненням атмосорерного повітря, кількістю днів 3 пиловими бурями та щільністю заселення місцевості. Поширення гіпертонічної хвороби найбільшою мірою залежить від двох чинників - рівня акустичного забруднення довкілля і характеру хімічних забруднень атмосорерного повітря. Наведені фракти свідчать про тісний зв'язок між станом навколишнього природного середовища і здоров'ям населення того чи іншого міста, селища, села, району, області та регіону загалом.

Сучасний етап соціально-економічного розвитку людської цивілізації чи не найбільшого удару завдав гідросфері - важливій складовій навколишнього природного середовища. Забруднення різних частин гідросфери набрали величезних масштабів. Високими темпами забруднюються ті водні ресурси, які є особливо важливими для людини, зокрема ріки, озера, прибережні зони морів та океанів, естуарії. У багатьох промислових центрах і великих містах прибережні води, що ще недавно були районами риболовства та відпочинку, перетворились на мертві зони. Ці водні об'єкти є корисними для суспільства не лише як джерела забезпечення його питною водою і продуктами харчування, a і як рекреаційні території. Проте інтенсивне забруднення їх виробничими та побутовими відходами і стоками, в яких містяться ртуть, кадмій, миш'як, свинець, нафртопродукти, пестициди, хвороботворні бактерії тощо, завдає значну матеріальну шкоду суспільству і загрожує здоров'ю та життю мільйонів людей.

Надзвичайно розповсюдженим джерелом захворюваності населення нині є забруднена питна вода. Так, за даними ООН, споживання недоброякісної води спричиняє захворювання на дизентерію, черевний тиф, холеру та інші іноекційні хвороби щорічно понад 500 млн осіб, з яких близько 10 млн помирають. Нині в Україні фактично все населення споживає воду низької якості. Наприклад, за більшістю показників якості водні ресурси в басейні р. Дніпро, зокрема його водосховищ і основних приток, належать до III та IV класів, тобто характеризуються переважно як забруднені та брудні. У багатьох населених пунктах навіть водопровідна вода є надмірно забрудненою шкідливими хімічними сполуками, важкими металами і пестицидами.

У сучасних умовах, коли поверхневі водні ресурси використовуються надто інтенсивно, значний вплив на них, а також на підземні води має забруднення промисловими та сільськогосподарськими стоками. Внаслідок цього ускладнюються умови господарсько-питного, виробничого і культурно-побутового водокористування та водозабезпечення. У промислових і сільськогосподарських стоках міститься значна кількість шкідливих речовин, зокрема й високотоксичних і стійких до впливу природних чинників самоочищення: нафтопродукти, важкі метали, синтетичні сполуки, хвороботворні мікроорганізми тощо.

Останніми десятиліттями спостерігається тенденція до зростання концентрації нітратів у поверхневих і підземних водних джерелах. Це зумовлено, насамперед, збільшенням використання в сільському господарстві азотних добрив, надходженням до водойм значної кількості органічних речовин тощо. Нітрати, за вмісту у продукції чи питній воді понад граничнодопустимі концентрації, спричиняють різкий негативний вплив на людський організм, особливо дитячий. Вони є чинником хронічних отруєнь, ураження внутрішніх органів, алергічних захворювань, та обміну речовин, підвищення метгемоглобіну в крові.

Дедалі посилюється забруднення грунту, («захімізованість» земельних ресурсів), а відтак - і продуктів харчування, вирощених на цих землях. Через грунти розповсюджується низка інфекційних хвороб (ботулізм, сибірська виразка, правець тощо). Серед застосовуваних у сільському господарстві пестицидів - чимало доволі стійких, що здатні передаватися через харчовий ланцюг і накопичуватися в рослинному або тваринному організмі. А відтак, вони потрапляють в організм людини, спричиняючи шкідливий вплив та низку важких захворювань.

Надмірна розораність території України майже в усіх її регіонах через відсутність проектів землеустрою у землекористувачів, а отже, екологічно незбалансовану структуру сільськогосподарських угідь і посівів сільськогосподарських культур, низьку культуру землеробства, майже повне припинення вжиття землеохоронних заходів тощо призвели не лише до зниження родючості грунтів, особливо чорноземів, а й до посилення ерозійних процесів, вимивання з грунту гумусу, азоту, фросфрору і калію. Все це, безперечно, негативно впливає на якість водних ресурсів, екологічну чистоту навколишнього природного середовища, зокрема гідросорери. А головне - завдає непоправної шкоди сільському господарству та його найважливішому виробничому ресурсу українським родючим грунтам.

Практика широкомасштабного застосування пестицидів у сільському й лісовому господарстві за останні десятиліття свідчить про їх шкідливий вплив на людський організм. Всі досліджувані агрохімікати виявляли мутагенну 
активність, тобто здатність змінювати спадковість. У мільйонів людей вони викликають алергічні реакції. Багато пестицидів і гербіцидів належать до канцерогенів. Крім того, їх застосування, подекуди необгрунтоване, у значних обсягах, насамперед пестицидів, згубно впливає й на живу природу, порушує нормальний хід біологічних, біохімічних та біофізичних процесів.

Разом із тим слід зважити й на те, що антропотехногенні чинники забруднення навколишнього природного середовища на сучасному етапі розвитку продуктивних сил суспільства значною мірою впливають на кругообіг речовин і хімічних елементів у біосфері загалом. Під їх впливом характер та швидкість біосферних процесів і явищ у навколишньому природному середовищі значно змінюються порівняно з відповідними процесами за нормальних умов, тобто за динамічної екологічної рівноваги. Внаслідок багатофункціональної та широкомасштабної виробничої діяльності в природне середовище потрапляють нехарактерні йому речовини, матеріали та сполуки. А тому природа не може їх асимілювати та знешкоджувати.

Антропотехногенні зміни обсягів вуглекислого газу в атмосферному повітрі, теплові й аерозольні забруднення біосорери як у глобальному, так і локальному масштабах, порушення циркуляційних процесів у Світовому океані та атмосорері, підвищення радіаційного фону тощо - всі ці чинники, зрештою, призводять до небезпечних змін і виникнення принципово незвичних явищ у біосфері. Останні, своєю чергою, не будуть індиферентними стосовно людини, бо в основній своїй масі негативно впливатимуть, з одного боку, на умови її життя та здоров' я, а 3 іншого — на відтворювальні процеси в природі та матеріальному виробництві.

Насамкінець, необхідно мати на увазі, що взаємовідносини суспільства і природи, взаємодія виробництва та біосфери, їх взаємні вплив і залежність на сучасному етапі розвитку людської цивілізації значно поглибились, ускладнились та урізноманітнились. Розглядаючи як єдине ціле інтегральну біосоціоекономічну систему «природа - суспільство - виробництво», а суспільство — як головний і надто динамічний компонент цієї системи, якій в ас- пекті природно-екологічних чинників властиво чітко фріксовані параметри, людство має усвідомити, що нині конче потрібно спромогтися досягти найраціональнішого використання й економного витрачання природних ресурсів у всіх галузях і сорерах діяльності. Крім того, слід докладати максимум зусиль щодо збереження та відтворення ресурсів біосфери, охорони навколишнього природного середовища від забруднення, виснаження, деградації і втрати ним екологічної безпеки.

Суспільні виробництво, обмін та споживання як чинники умови існування людини наразі обов' язково необхідно сумлінно «вписувати» в біосферу, щоб не виникали негативні наслідки, незворотні шкідливі явища і зміни, спроможні призвести до різкого погіршення природних життєвих умов суспільства, катастрофічного зниження екологічної безпеки й якості питної води, атмосорерного повітря та продовольства. Оскільки суспільство не має змоги безпосередньо «вписатися» у біосорерні процеси через відсутність власної екологічної ніші, то воно повинно оптимально узгоджувати свій соціально-економічний розвиток 3 ресурсними можливостями біосорери та з дією екологічних законів.

Висновки. Кожна країна, яка стала на шлях науково-технічного прогресу і широкомасштабного використання його результатів, не має права ігнорувати такі об'єктивні чинники, як вичерпаність деяких природних ресурсів, насамперед невідтворюваних і невідновлювальних, уразливість навколишнього природного середовища, його екологічну стійкість та екологічну місткість, межі екологічної міцності й опірності. Всі перелічені чинники, як і комплексний вплив на них інтенсивної господарської діяльності та високих темпів демографічного розвитку в багатьох країнах світу, нині необхідно всебічно враховувати під час розробки бізнес проектів. Це, своєю чергою, потребує глибокого вивчення екологічних особливостей навколишнього природного середовища, складних і взаємозалежних явищ, які відбуваються в біосфері під впливом господарської діяльності людини, різноманітних суспільно-політичних, соціально-економічних, виробничих і демографічних процесів.

\section{СПИСОК ВИКОРИСТАНИХ ДЖЕРЕЛ}

1. Гуцуляк Ю.Г. Концептуальний підхід до конструювання агроекосистем: сталий екологобеспечний розвиток природокористування. Чернівці: Прут, 2009. 48 с.

2. Шкуратов O.I. Організаційно-економічні основи екологічної безпеки в аграрному секторі України: теорія, методологія, практика: монографія. К.: ДКС-Центр, 2016. 356 с.

3. Гуцуляк Г.Д., Гуцуляк Ю.Г. Теоретико-методичні засади сталого розвитку // Засади сталого розвитку Косівщини: монограф. наук. праці. Чернівці: Прут, 2005. С. 9-82. 
4. Дягодюк Є.Г., Сайко В.Ф., Корнійчук М.С. та ін. Вирощування екологічно чистої продукції рослинництва. К.: Урожай, 1992. 320 с.

5. Реметюк А.Л. Науково-технічний прогрес і проблеми гігієни праці. К.: 1978. 247 с.

6. Фурдичко O.I. Екологічні основи розвитку агросфери в контексті європейської інтеграції України. К.: «ДIА», 2014. 432 с.

7. Шкуратов О.І. Удосконалення інструментарію організаційно-економічного забезпечення екологічної безпеки в аграрній сфері // Вісник Сумського національного аграрного університету. Серія: Економіка і менеджмент. 2016. Вип. 4 (68). С. 171-175.

8. Мишенин Е.В., Семененко Б.А., Мишенина Н.В. Экономический механізм экологизации производства. Сумы: ИПП «Мрия-1» ЛТД, 1996. 140 с.

9. European Council. Green Paper on market-based instruments for environment and related policy purposes. Brussels, 2007. SEC (2007) 388. 33 p.

10. Фурдичко O.I., Шкуратов O.І. Стратегічне управління екологічною безпекою в аграрному секторі // АгроСвіт. 2016. № 8. С. 3-8.

11. Эрисман Ф.Ф. Краткий учебник по гигиене. [3-е изд]. М.: Карцев, 1912, 524 с.

\section{Інформація про авторів}

Гуцуляк Григорій Дмитрович — доктор економічних наук, професор, член-кореспондент НААН, головний науковий співробітник, Прикарпатська державна сільськогосподарська дослідна станція Інституту сільського господарства Карпатського регіону (Україна, 76006, м. Івано-Франківськ вул. Степана Бандери, 21a; e-mail: dubkosiv@gmail.com)

Гуцуляк Юрій Григорович - доктор економічних наук, старший науковий співробітник, провідний науковий співробітник, Прикарпатська державна сільськогосподарська дослідна станція Інституту сільського господарства Карпатського регіону (Україна, 76006, м. Івано-Франківськ вул. Степана Бандери, 21a; e-mail: yuriy.kosiv@gmail.com).

H.D. Hutsuliak

Doctor of Economic Sciences, Professor

Corresponding Member of NAAS

Transcarpathian State Agricultural Research Station of the Institute of Agriculture of the Carpathian Region (Ukraine, Ivano-Frankivsk; e-mail: dubkosiv@gmail.com)

Yu.H. Hutsuliak

Doctor of Economic Sciences, Senior Researcher

Transcarpathian State Agricultural Research Station of the Institute of Agriculture of the Carpathian Region (Ukraine, Ivano-Frankivsk; e-mail: yuriy.kosiv@gmail.com)

\section{PRINCIPLES OF EVALUATION OF ECOLOGICAL SITUATIONS}

The factors that need to be fully taken into account when conducting intensive economic activity are determined, which, in turn, requires a deep study of the environmental features of the environment, complex and interrelated phenomena that occur in the biosphere under the influence of human economic activity, various socio-political, socio-economic, industrial and demographic processes. The principles that need to be guided when performing specific tasks of a spatial analysis of environmental situations and their assessment are justified: the principle of the dependence of the formation and development of environmental situations on natural and socio-economic factors; the principle of compliance (mismatch) of the anthropogenic load of the sustainability potential and the natural resource potential of the landscape; the principle of environmental significance of natural and socio-economic factors; priority principle; the principle of duration, discontinuity in the development of environmental situations; the principle of danger and risk of an environmental situation; modular principle; combination principle.

Keywords: principles, economic activity, ecological features, natural environment, economic activity, anthropogenic impact.

\section{REFERENCES}

1. Hutsuliak, Yu.H. (2009). Kontseptualnyi pidkhid do konstruiuvannia ahroekosystem stalyi ekolohobespechnyi rozvytok pryrodokorystuvannia [A conceptual approach to agroecosystem design: sustainable environmental development]. Chernivtsi: Prut. 48. (In Ukr.) 
2. Shkuratov, O.I. (2016). Orhanizatsiino-ekonomichni osnovy ekolohichnoi bezpeky $v$ ahrarnomu sektori Ukrainy teoriia metodolohiia praktyka [Organizational and economic bases of ecological safety in the agrarian sector of Ukraine: theory, methodology, practice]. Kyiv: DKS-Tsentr. 356. (In Ukr.)

3. Hutsuliak, H.D. \& Hutsuliak, Yu.H. (2005). Teoretyko-metodychni zasady staloho rozvytku [Theoretical and methodological principles of sustainable development]. Zasady staloho rozvytku Kosivshchyny [Principles of sustainable development of Kosiv region]. Chernivtsi: Prut. 9-82. (In Ukr.)

4. Diahodiuk, Ye.H., Saiko, V.F., Korniichuk, M.S. etc. (1992). Vyroshchuvannia ekolohichno chystoi produktsii roslynnytstva [Growing environmentally friendly crop production]. Kyiv: Urozhai. 320. (In Ukr.)

5. Remetiuk, A.L. (1978). Naukovo-tekhnichnyi prohres i problemy hihiieny pratsi [Scientific and technological progress and problems of occupational health]. Kyiv, 247. (In Ukr.)

6. Furdychko, O.I. (2014). Ekolohichni osnovy rozvytku ahrosfery v konteksti yevropeysekoyi intehratsiyi Ukrayiny [Ecological bases of agrosphere development in the context of European integration of Ukraine]. Kyiv: DIA. 432. (In Ukr.)

7. Shkuratov, O.I. (2016). Udoskonalennia instrumentariiu orhanizatsijno-ekonomichnoho zabezpechennia ekolohichnoi bezpeky v ahrarnij sferi [Improvement of the organizational and economic provision of environmental safety in the agrarian sector]. Visnyk Sums'koho natsional'noho ahrarnoho universytetu. Seriia: Ekonomika $i$ menedzhment [Visnyk of the Sumy National Agrarian University. Series: Economics and Management], 4 (68). 171-175. (In Ukr.)

8. Mishenin, E.V., Semenenko, B.A. and Mishenina, N.V. (1996) Ekonomicheskiy mehanizm ekologizatsii proizvodstva [Economic mechanism of greening production]. Sumy: IPP «Mriya-1» LTD.140. (In Russ.)

9. European Council. Green Paper on market-based instruments for environment and related policy purposes. Brussels, 2007. SEC (2007) 388. 33.

10. Furdychko, O.I. \& Shkuratov, O.I. (2016). Stratehichne upravlinnia ekolohichnoiu bezpekoiu v ahrarnomu sektori [Strategic management of environmental safety in the agrarian sector]. AhroSvit [AgroSvit], 8. 3-8. (In Ukr.)

11. Erisman, F.F. (1912). Kratkij uchebnik po gigiene. 3-e izd. [A short textbook on hygiene. 3rd ed.]. Moscow: Karcev. 524. (In Russ.)

\section{Authors}

Hutsuliak Hryhorii Dmytrovych - Doctor of Economic Sciences, Professor, Corresponding Member of NAAS, Chief Research Fellow, Transcarpathian State Agricultural Research Station of the Institute of Agriculture of the Carpathian Region (Ukraine, 76006, Ivano-Frankivsk, 12a Stepan Bandery st.; e-mail: dubkosiv@gmail.com)

Hutsuliak Yurii Hryhorovych - Doctor of Economic Sciences, Senior Researcher, Leading Research Fellow, Transcarpathian State Agricultural Research Station of the Institute of Agriculture of the Carpathian Region (Ukraine, 76006, Ivano-Frankivsk, 12a Stepan Bandery st.; e-mail: yuriy. kosiv@gmail.com). 